\title{
Ditadura, repressão e resistência: memórias de um militante político
}

\author{
Milene Cristina Hebling*
}

Luiz Marcos de Magalhães Gomes, ${ }^{1}$ jornalista mineiro, é conhecido por suas ações de resistência ao regime militar e por sua intensa participação política. Sua militância iniciou-se ainda enquanto cursava o ensino de $2^{\circ}$ grau e continuou durante sua formação universitária, na qual participou ativamente do diretório acadêmico e iniciou sua atuação na Ação Popular (AP). Devido à sua participação no movimento estudantil, viajou por diversas cidades brasileiras e, inclusive, para o exterior. Sua militância na AP iniciou-se em Belo Horizonte, cidade na qual sofreu sua primeira prisão. Após o Ato Institucional n ${ }^{\circ} 5$, mudou-se para São Paulo e, posteriormente, para o Rio de Janeiro, cidades nas quais continuou desenvolvendo seu trabalho nessa organização. Através dessas experiências políticas, entrou em contato com importantes líderes do movimento de resistência à ditadura militar brasileira e consolidou sua posição contrária ao regime.

Luiz integrou a equipe de importantes jornais de oposição ao governo, como o Opinião e o Movimento. Devido à sua participação ativa na Ação Popular, sofreu com a repressão do regime. Luiz destacou, durante as horas de gravação da entrevista, a repressão sofrida não apenas em âmbito policial, mas também nas esferas pessoal e social.

A autora deste texto desenvolve a pesquisa de mestrado intitulada A resistência dos professores à ditadura militar no Brasil: entre documentos

\footnotetext{
* Mestranda em Educação pela Universidade Federal de São Carlos (UFSCar). Bolsista da Fundação de Amparo à Pesquisa do Estado de São Paulo (Fapesp).

1 O entrevistado concedeu autorização à pesquisadora para a divulgação de seu nome.
} 
oficiais e memórias reveladas, a história de uma luta, projeto não institucional, que tem como objetivo geral identificar as práticas de resistência à ditadura estabelecidas por professores que lecionaram nos níveis de $1^{\circ}$ ou $2^{\circ}$ graus no período. A estratégia metodológica adotada foi a história oral, o que levou à realização de um total de quatro entrevistas, incluindo a de Luiz Marcos. Esse acervo oral está, no momento, sob os cuidados da pesquisadora. A dissertação resultante de tal pesquisa irá conter a transcrição de todas as entrevistas realizadas, a fim de disponibilizá-las para consultas.

Para selecionar os participantes da referida pesquisa, realizou-se uma extensa busca no acervo documental do Departamento Estadual de Ordem Política e Social (Deops), disponível no Arquivo do Estado de São Paulo. Durante essa busca, foram encontrados documentos referentes à prisão de Luiz Marcos, que o identificavam como sendo professor. Contudo, durante a entrevista, ele revelou que essa informação foi prestada aos agentes policiais apenas como um meio de proteger a si e à sua família, visto que se dedicou profissionalmente ao jornalismo.

Apesar de não fazer parte do grupo que a pesquisa citada focaliza, ou seja, professores que lecionaram durante a ditadura militar, Luiz Marcos forneceu importantes elementos de análise, até mesmo sobre a educação no período. Sua entrevista expóe claramente o ambiente repressor existente durante o regime militar. Além disso, ele analisa a formação da esquerda brasileira, explicita as principais teorias que embasavam os grupos de resistência à ditadura militar e os motivos de divergência entre esses grupos. Os elementos apontados por esse jornalista permitem compreender as dificuldades vivenciadas por um militante, que abrangiam desde a prisão e a tortura até a dificuldade em concluir um curso universitário ou encontrar um emprego após ter sido fichado por um órgão de polícia política. Em sentido mais amplo, é possível também identificar o funcionamento do aparato repressor organizado pelos militares e, assim, compreender um pouco mais sobre como o regime construiu um de seus principais pilares de sustentação, ou seja, a vigilância e a punição a todos os que apresentassem posições divergentes daquelas defendidas pelo governo.

A entrevista deveria ser conduzida através de um questionário semiestruturado, com questões abertas e organizadas em bloco, a fim de possibilitar a sequência narrativa ao participante. Contudo, talvez devido à sua profissão, Luiz Marcos narrou detalhadamente os acontecimentos pelos quais passou durante o regime militar, respondendo antecipadamente muitas das 
questões previstas. A transcrição respeitou as características da linguagem oral. $\mathrm{O}$ entrevistado recebeu uma cópia da versão escrita para que verificasse a necessidade de possíveis alterações ou supressões, a fim de resguardar sua privacidade, respeitando sempre a ética necessária à pesquisa.

\section{Entrevista}

Milene - Eu gostaria que você começasse contando sobre sua vida, sua formação, onde você nasceu, para eu te conhecer um pouco.

Luiz Marcos - Bom, meu nome é Luiz Marcos Magalhães Gomes, eu nasci em Belo Horizonte, tenho 66 anos e sou de uma família de classe média - meu pai era professor universitário, professor de física das escolas de Engenharia e Filosofia da Universidade Federal de Minas Gerais (UFMG) e depois ele foi o primeiro diretor aqui, após a Reforma Universitária, do Instituto de Ciências Exatas. Eu estudei inicialmente no Colégio Marista, onde eu fiz o $1^{\circ}$ grau. Depois estudei no Colégio Loyola, dos jesuítas, onde eu fiz o ginásio e o científico e, em 1964, eu ingressei na Faculdade de Ciências Econômicas da UFMG, exatamente no ano do golpe. Eu já tinha uma militância estudantil secundarista, apesar de o Colégio Loyola ser muito contrário, né. Os padres eram extremamente repressores e não permitiam muita atividade estudantil. Mas, em que pese isso, a gente fundou o grêmio, fizemos um jornal, fizemos um grupo de teatro, fizemos um cineclube. Era também uma época muito - aí eu estou me referindo a 1963 - era uma época de muita efervescência na juventude. As entidades tanto secundaristas quanto universitárias tinham muita atividade em todos os sentidos. Não era só atividade política, não, mas muita atividade cultural - estou te falando de teatro, cinema. E eu entrei então na faculdade no ano do golpe. Como aconteceu na maior parte dos lugares, aqui também houve uma repressão muito grande no movimento estudantil, houve intervenção no diretório acadêmico, no Diretório Central dos Estudantes (DCE) da UFMG, que era a mais importante entidade aqui local. Houve também intervenção em vários diretórios acadêmicos. A Faculdade de Ciências Econômicas era uma faculdade muito politizada. Ela tinha os cursos de sociologia, economia e administração de empresas. Posteriormente, o curso de sociologia saiu de lá porque a Faculdade de Filosofia 
também tinha um curso de ciências sociais. Mas o curso de sociologia da Faculdade de Ciências Econômicas politizava muito a faculdade. Para você ter uma ideia, essa é a faculdade em que estudaram pessoas como Betinho, o Herbert José de Souza; o Vinícius Caldeira Brant, que foi presidente da União Nacional dos Estudantes (UNE) antes do Serra. Se não me engano, a gestão dele foi 62/63. Pessoas como o Jair Ferreira de Sá, que foi um importante dirigente da Ação Popular; pessoas como o João Baptista Franco Drummond, que é um dos assassinados pela ditadura militar. Ele foi dirigente da Ação Popular depois do Partido Comunista do Brasil (PC do B) e foi morto naquele incidente da Lapa em 1975. E também tem pessoas que foram mortas, outras pessoas mortas como o militante da Ação Popular, Gildo Lacerda. Então era uma faculdade que foi um dos berços da AP e da Polop [Organização Revolucionária Marxista Política Operária]. Também outro militante muito importante, dirigente da Polop, Carlos Alberto Soares de Freitas, que foi morto naquela famosa casa da repressão em Petrópolis, conhecida como Casa da Morte, e até hoje está desaparecido. Era uma faculdade então, muito politizada. Houve intervenção no diretório, mas logo na primeira eleição, os estudantes elegeram nova chapa, contra a ditadura. O primeiro presidente do Diretório Acadêmico foi o João Baptista Franco Drummond, esse que eu falei pra você que foi morto pela repressão quando caiu a direção do PC do B na Lapa e, posteriormente, em 65, eu o substituí. Fui eleito também presidente do Diretório Acadêmico quando eu estava no segundo ano da faculdade.

\section{M - Que curso você estava fazendo?}

LM - Eu estava fazendo o curso de economia. Em 1966, porque aqui aconteceram muitas manifestações, talvez as primeiras manifestações do movimento estudantil, já em 65, 66, houve muita repressão. E o movimento estudantil mineiro tinha um nível de mobilização muito alto. Então, em 1966, foi realizado aqui em Belo Horizonte, em julho, o XXVIII Congresso da União Nacional dos Estudantes. Eu participei desse congresso porque eu era presidente do Diretório da Faculdade de Ciências Econômicas e, nesse congresso, eu fui eleito vice-presidente da UNE. Eu já tinha ligação com a organização chamada Ação Popular que, como você sabe, depois do golpe militar foi das primeiras organizações a, digamos assim, decidir pela resistência armada, fazendo análise do caráter da ditadura, das consequências. Mas ela não se engajou tanto na chamada luta armada urbana. Ela teve um período 
em que foi muito ligada aos cubanos, ao que a gente então chamava de teoria do foquismo, o chamado "foco revolucionário", mas ela transitou, logo em seguida, mais para uma concepção maoísta, denominada guerra popular, que era uma visão assim - vou simplificar muito - de você preparar a luta armada a partir do campo, que era considerado o elo mais fraco da repressão. A gente considerava que você preparar luta armada na cidade, onde se concentrava a maior parte dos contingentes militares e paramilitares, policiais militares e polícia civil, era uma coisa que não tinha muito futuro. Você poderia, como aconteceu com outras organizações, fazer algumas ações preliminares com muito sucesso, mas depois você iria enfrentar uma reação dessa repressão muito forte. E nessas cidades, como Rio de Janeiro, Belo Horizonte, São Paulo, onde elas tinham uma concentração de forças muito grande. Eu fiz só esse parêntese pra dizer que eu era ligado então à Ação Popular quando eu fui eleito vice-presidente da UNE. Quem encabeçava a chapa era o ex-presidente da União Estadual dos Estudantes (UEE) mineira, chamado José Luiz Moreira Guedes. Então eu fui vice-presidente da UNE de julho de 66 a julho de 67 . E durante todo esse período, eu praticamente me afastei da faculdade e fiquei viajando pelo Brasil, porque essa era a posição da direção da Ação Popular. A Ação Popular tinha a maioria nessa chapa e nós ficamos então praticamente um ano viajando pelo Brasil inteiro, de ônibus e... a UNE era ilegal, era perseguida, mas era muito reconhecida pelos estudantes. E a gente era muito atrevido, a gente ia para os lugares, falava em sala de aula, chegava, participava das manifestações, se identificava. Então foi um ano assim de muita militância. Eu estive também no Uruguai, em Montevidéu, participando de um encontro da Oclae - Organização Continental Latino-Americana de Estudantes, que tinha sede em Havana - e também me encontrei com o presidente João Goulart, em Punta Del Leste, que estava no exílio. E ele inclusive ofereceu ajuda e ajudou na organização do $29^{\circ}$ Congresso da UNE, que foi realizado em Valinhos, em julho de 1967, ali perto de Campinas, em que foi eleito então o Luiz Travassos. Então, largando a UNE em 1967, eu voltei para Belo Horizonte, voltei a frequentar a faculdade, mas nesse ano eles mudaram a regra. Eu tinha tomado bomba em frequência em 66, por causa dessa militância. Em 67, também frequentei pouco e aí eu fui impedido de fazer segunda chamada e eles me jubilaram. Excluíram-me da faculdade sem nenhuma explicação maior. Simplesmente mudaram as regras. Eu continuei na Ação Popular e aí comecei a participar mais do movimento operário. Em 1968, aqui em Belo Horizonte, teve uma importante greve operária em abril, dos metalúrgicos. Aqui tem a 
cidade industrial de Contagem, que é colada em Belo Horizonte, na região metropolitana. E a greve começou na trefilaria da Belgo Mineira, que ainda é uma das principais fábricas metalúrgicas da região metropolitana. Depois, entre abril e outubro, eu me mudei para a cidade industrial, com vários outros militantes da Ação Popular. A Ação Popular tinha nessa época uma política que a gente chamava de "integração na produção", tanto em relação ao trabalho camponês quanto ao trabalho operário. Mas eu não cheguei a trabalhar em fábrica porque eu era, digamos assim, muito manjado, muito conhecido, mas eu me mudei para um bairro da cidade industrial. Vivi lá alguns meses e em outubro de 68 houve outra greve, aí já com uma participação mais intensa dos operários e militantes deslocados da Ação Popular. Na antevéspera dessa greve, eu fui preso, na cidade industrial, com o líder da greve, Ênio Seabra, a gente tinha acabado de sair de uma reunião. O Dops [Departamento de Ordem Política e Social] vinha ali fazendo uma batida e nós fomos abordados e fomos presos. Mas mesmo assim, no dia seguinte, a greve foi deflagrada. Eu fiquei dois meses preso, passei por muitas unidades prisionais aqui em Belo

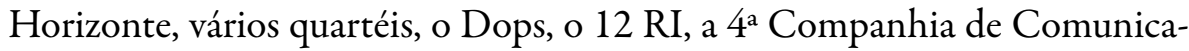
ções. Eu tive um problema sério, porque eu peguei uma hepatite na prisão. Acho que foi, inclusive, uma hepatite transmitida de propósito, porque eles falaram, quando eu estava preso ali numa unidade deserta, na $4^{\text {a }}$ Companhia de Comunicaçóes, falaram que todos os presos tinham que tomar uma injeção porque havia uma epidemia e uma semana depois, eu apareci com a hepatite. Tive um problema grave porque eles me impediram de ir para o hospital e foi só devido a uma grande manifestação dos presos políticos que então estavam no Dops, para onde eu fui transferido, é que eu tive assistência médica. Aí, depois de dois meses, que era o período que você poderia ficar preso sem condenação, eu acabei solto e continuei aqui em Belo Horizonte. Aí você sabe que no dia 13 de dezembro veio o AI-5, 13 de dezembro de 68. Eles mandaram um telegrama para os meus pais, na casa dos meus pais, para eu me apresentar e aí eu fui - por decisão da própria direção da Ação Popular - eu fui para São Paulo, mais ou menos em março de 1969. Eu era casado e tinha uma filha de poucos meses, minha filha mais velha.

$\mathbf{M}$ - E você foi sozinho?

LM - Não. Eu fui com a minha esposa e fui com a minha filha porque, de certa maneira, todos os três estavam sob ameaça. Em São Paulo, eu me integrei 
no trabalho operário da Ação Popular, no ABC. Poucos meses depois, eu estava morando no bairro Vila Califórnia, que é um bairro de São Caetano e, em dezembro de 69, eu fui preso em São Paulo. Eu estava na Avenida do Estado cobrindo um ponto, houve uma batida e eu fui preso com outro dirigente da Ação Popular, que já faleceu, infelizmente, chamava Marcelo Hugo de Medeiros, um engenheiro. Nós dois fomos presos. Fomos presos e levados para o Dops, eu passei por todas essas conhecidas torturas. Ficamos 40 dias sem que a repressão reconhecesse nossa prisão. Eu também passei pela Ilha das Flores, no Rio, o que foi um sequestro porque isso não consta da minha ficha oficial das autoridades de São Paulo que me prenderam. Eu fui levado para o Cenimar [Centro de Informações da Marinha] pelo Delegado Fleury, eu e o Marcelo, e eu fiquei preso até 1971, mais ou menos setembro. Eu fui condenado inicialmente a quatro anos de prisão e depois, em um recurso ao Superior Tribunal Militar, foi reduzido para dois e esses dois eu já tinha cumprido. Então eu fui solto, mais ou menos em outubro/setembro de 1971, eu e o Marcelo. O Marcelo era paraibano, voltou para sua terra. Meu pai, muito preocupado, quis me mandar para o exterior, mas eu resisti um pouco porque eu já tinha cumprido pena, eu tinha estado no Uruguai, como eu te disse, vi a vida dos exilados também, coisa muito difícil. Além disso, eu tinha também minha filha, que já estava com dois anos e oito meses. Então, eu, minha esposa e minha filha nos mudamos para o Rio de Janeiro. Fui trabalhar, inicialmente em publicidade. Eu já era jornalista, mas ninguém aceitava me empregar. Aí eu fui trabalhar em publicidade para sobreviver. E, um ano depois, quando um grupo de jornalistas fez um acordo com o Fernando Gasparian, que era um empresário de oposição à ditadura, para fundar o jornal Opinião, aí através de um dos meus irmãos, eu fiquei conhecendo o jornalista Raimundo Rodrigues Pereira, porque eles tinham sido colegas no ITA [Instituto Tecnológico de Aeronáutica] e tinham sido desligados do ITA em 1964. E eu fui trabalhar desde o começo no jornal Opinião, onde eu fiquei até 1975, quando a gente divergiu com o proprietário do jornal, Fernando Gasparian, e nós partimos então para fundar o jornal Movimento. O jornal Opinião funcionava no Rio, foi um dos mais importantes jornais de resistência à ditadura militar, mas o jornal Movimento foi fundado em São Paulo porque a gente achava que lá as condições eram mais favoráveis. Eu fui um dos fundadores do jornal Movimento e trabalhei lá até 1981.

M - Então você voltou para São Paulo? 
LM - Voltei para São Paulo. Então é mais ou menos isso... Aí em 82, eu voltei para Minas Gerais, porque o jornal Movimento fechou em 81. Continuei minha militância. Tive um período ligado ao $\mathrm{PC}$ do $\mathrm{B}$, porque a maioria da Ação Popular tinha resolvido se integrar no PC do B, mas me afastei também depois por divergências políticas. Não me identifico mais com esse partido. Aliás, falando rigorosamente, não me identifico hoje com nenhum partido desses legais que estão aí. Eu me considero um militante marxista, mas sem partido e buscando uma alternativa ainda. Apesar de ter 66 anos, tento acompanhar a vida política do país e tal.

M - E, durante esse período, você concluiu sua faculdade ou fez curso de jornalismo?

LM - Não, como eu te disse, fui desligado da Faculdade de Ciências Econômicas da UFMG em 66. Em 1974, como nenhuma faculdade - nem particular nem pública - aceitava minha transferência, eu prestei outro vestibular de economia na Faculdade Cândido Mendes, no Rio. Passei no vestibular e, apesar deles terem reconhecido poucos créditos, eu comecei a frequentar e frequentei dois anos. Em 1977, houve um racha importante no jornal Movimento e o jornal ficou muito enfraquecido. Houve um apelo muito grande para que eu me mudasse para São Paulo, porque até então eu trabalhava com o Movimento, mas na sucursal do Rio de Janeiro. Então houve uma pressão muito grande para que eu fosse para São Paulo. E o que aconteceu? Eu mudei para São Paulo de novo em 77 e, com isso, tive de arrumar outra faculdade de economia, no caso foi a Fundação Armando Álvares Penteado, uma faculdade aliás muito chata, porque era uma faculdade muito de elite, mas ela era a mais próxima da redação do jornal Movimento, que ela ali em Pinheiros, na rua Virgílio de Carvalho Pinto. Eu consegui a transferência para a FAAP [Fundação Armando Alvares Penteado], no curso de economia, mas eles me jogaram de novo no segundo ano. E eu acabei terminando meu curso de economia só em 1980, depois de passar por três faculdades, cursar mais ou menos oito anos e fazer dois vestibulares. Mas como o Brasil, você sabe, é um país muito cartorial, e eu pretendia voltar para Minas Gerais e aqui as condições da imprensa sempre foram muito ruins, acho que eu dificilmente conseguiria trabalhar aqui como jornalista, porque eu era jornalista por direito adquirido. Eu não fiz curso de jornalismo. Desde 63, eu trabalhei também como jornalista. Trabalhei aqui no jornal $O$ Diário, que era ligado à arquidiocese. 
Depois trabalhei aqui na Rádio Tiradentes, que era ligada à Rede Globo, como redator e, depois, quando eu fui preso, evidentemente essa carreira foi interrompida. Mas eu me formei assim, do ponto de vista formal, em ciências econômicas, na Faculdade de Economia da Fundação Armando Alvares Penteado em São Paulo.

M - Você segue a linha marxista. Você começou a seguir essa linha devido à sua militância, por influência de seu curso ou por outro motivo?

LM - Se você analisar a esquerda no Brasil, como um todo - e também com uma visão muito simplificada, já que nossa entrevista aqui tem seu tempo definido - você vê que, no Brasil, a esquerda tem vários leitos, vamos dizer assim, várias origens. Uma das principais, senão a principal, é o leito comunista. O Partido Comunista do Brasil foi fundado em 1922 por um pequeno grupo em um congresso realizado em Niterói. E esse é um leito muito rico. Como houve muitos rachas, etc., você pode ver que uma das linhas segue o PCB, depois tem linhas trotskistas, depois o PCB sofreu muitos rachas, em 62 surge o PC do B, né. Depois, o próprio PCB deu origem ao PPS, mas teve um pessoal que não abriu mão do nome do $\mathrm{PCB}$ e o $\mathrm{PCB}$ ainda existe até hoje, como uma das organizações e, aliás, ambos - PCB e PC do B - disputam até, nesse ano de 2012, a comemoração dos 90 anos da fundação do Partido. Porque cada um deles se acha herdeiro das tradições dessa linha comunista. Uma outra linha importante na militância no Brasil, nessas formações, é digamos, uma linha mais nacionalista, que é bem diferente da tradição marxista. É a linha do PTB, de várias facções nacionalistas, que deram origem ao getulismo, depois ao brizolismo, ao trabalhismo e, depois do golpe, esse pessoal fez a Guerrilha do Caparaó. Tem toda essa tradição da linha nacionalista, que também tem muitas ramificações. Surgiram muitos movimentos de resistência dentro dessa linha nacionalista e, depois até da Anistia e da redemocratização, o Brizola organizou - eles perderam a sigla do PTB para a Ivete Vargas, que era uma linha auxiliar do regime - e eles organizaram o PDT. Tinha um outro leito, que é mais ou menos ao qual eu pertenço, que era o da chamada Ação Católica e, posteriormente, da Esquerda Católica. A Ação Popular tem origem mais nesse leito. Não era um leito inicialmente marxista. Era um leito inicialmente ligado às chamadas "Juventudes Católicas": Juventude Estudantil Católica, Juventude Universitária Católica. E esse leito também cresceu muito no começo dos anos 60 e teve uma influência 
muito grande no movimento estudantil. Tanto que você vê que alguns dos presidentes mais lembrados da UNE - Aldo Arantes, José Serra, Vinícius Caldeira Brant; depois da ditadura: José Luiz Guedes, Luiz Travassos - todos esses eram ligados à Ação Popular. A Ação Popular passou por muitas fases. Ela surgiu inicialmente como um movimento democrático, reformista porque também, nessa época, o PCB, que tinha muita influência no movimento de massas, estava com uma linha de baixa resistência. Então era uma época de radicalização e o PCB perdeu muita influência e abriu espaço para outras forças. A Ação Popular foi uma dessas forças, com origem na Ação Católica, que ocupou muito espaço e se ligou muito à luta de massas. Após o golpe militar de 64, a Ação Popular passou por uma segunda fase, quando ela se definiu por uma organização revolucionária que ia preparar a luta armada. Isso foi uma outra etapa, digamos assim, uma segunda etapa, né. Muita gente se distanciou dela nessa época por causa dessa definição... E como ela foi uma organização que se ligou muito ao movimento de massas estudantil, camponês e operário, foi mais ou menos inevitável o encontro dela com a teoria marxista. Porque se você milita, do ponto de vista político, leva a sério, você inevitavelmente ou cai no espontaneísmo, uma coisa meio sem muito futuro, ou tem de encontrar uma teoria que te ajude. E, evidentemente na minha opinião, a teoria mais rica, mais envolvida e que mais reflete a tradição revolucionária da luta de classes era o marxismo. Então, a Ação Popular inevitavelmente marchou em direção ao marxismo. E como eu era um militante muito ativo, fui inclusive dirigente aqui em Minas Gerais, fui dirigente em São Paulo e fui da Comissão Nacional Operária, eu também segui esta trajetória. Para nós, a descoberta do marxismo foi assim uma mina de ouro, do ponto de vista que nós estávamos procurando respostas estratégicas, respostas táticas, respostas ideológicas às nossas preocupações e à nossa prática política. E quem melhor, seguramente, respondeu como uma ferramenta de ação a essas indagações foi o marxismo. Claro que houve influência da faculdade e tal, mas não foi uma coisa local, entendeu? Foi um processo de evolução, digamos assim, da organização a que eu estava ligado e também a luta de massas que a gente estava muito ligado, a luta concreta, as manifestações. Nós não éramos eminências pardas que ficavam por trás das lutas confabulando. Eu fui presidente de diretório, participei de inúmeras manifestações, de passeatas, de comícios, eu participei de greves operárias, fui para bairro industrial, fui preso, quer dizer, a gente tinha uma militância muito intensa. 
M - Eu imaginei que não fosse devido ao seu curso por ser um curso de exatas, apesar de não conhecer a faculdade que você iniciou aqui, a UFMG.

LM - É, na Faculdade de Ciências Econômicas, normalmente, o presidente do diretório era do curso de economia porque era o curso mais numeroso. $\mathrm{O}$ curso de economia também era muito politizado. Eu não digo que tinha influência marxista assim muito intensa. Não tinha. Mas o curso também era muito politizado. $\mathrm{O}$ curso de sociologia era mais politizado. A faculdade era uma faculdade com muita efervescência, tanto que você vê que não foram todos os diretórios acadêmicos que sofreram intervenção aqui em 64 . O de ciências econômicas foi um dos que sofreu intervenção porque era uma faculdade de militância muito grande e tem todos esses quadros que eu te disse, notadamente da AP e da Polop, que eu te apontei, que saíram daquele meio. Então era das escolas mais politizadas na época do golpe e mesmo posterior ao golpe, no âmbito aqui da UFMG. E você deve considerar também que, naquele momento, o público universitário era um público com uma configuração muito diferente do que é hoje. Hoje predomina largamente, nos estudantes universitários, pelo que eu sei, o público que estuda nas faculdades privadas. Naquela época, eu estou falando dos anos 60 , a maior parte dos estudantes universitários de Belo Horizonte, de Minas Gerais e do país estavam em escolas públicas federais. Mesmo a Universidade Católica, que hoje tem talvez 60 mil estudantes e tal, era também uma coisa muito reduzida. Então também a configuração do público universitário era bem diferente. Era um público muito mais reduzido. Quer dizer que houve uma democratização aí evidentemente óbvia do ensino superior, mas houve também uma presença avassaladora das faculdades privadas que, às vezes, não tem tanta tradição política quanto as escolas públicas, universidades públicas. [...] O diretório acadêmico da faculdade, antes do golpe, mantinha um cursinho. Eu não fiz cursinho para ingressar na faculdade, o que era muito comum, porque nós organizamos no Colégio Loyola - nossa turma era muito ativa - nós mesmos organizamos um esquema de estudo de todos aqueles que prestaram vestibular em 64, que se formaram em 63 no científico e que prestaram vestibular no início de 1964, para as mais variadas [áreas]. Todos prestaram vestibular para a UFMG. Então nós organizamos, no Colégio Loyola, em uma sala lá, um esquema de estudo. A gente tinha aula de manhã e toda tarde a gente voltava lá e ficava estudando. Então nós, a minha turma especificamente não entrou em cursinho, o que era muito normal naquela época. O diretório acadêmico 
da Faculdade de Ciências Econômicas tinha um cursinho. Ele tinha um cursinho, administrava o restaurante, administrava uma cooperativa de livros, tinha uma atividade de fornecer bolsas, tinha uma espécie de um concurso, um vestibulinho, que fornecia bolsas para estudantes que eram do interior, ele tinha uma estrutura. Com a intervenção da ditadura em 64, tudo isso foi fechado. Então, eu fiz bico, trabalhei como jornalista, como eu te disse, na Rádio Tiradentes que foi a pioneira aqui, da Rede Globo e tal. [...]

M - Pelo que eu percebi, você sempre foi bastante crítico em relação à política. Você acha que essa sua postura se deve à sua formação tanto escolar quanto familiar, devido a esse ambiente cultural em sua casa?

LM - Acho que se deve muito à minha formação familiar, sim. E à minha formação escolar, pelo exemplo negativo, porque eu sempre tive muito problema disciplinar, tanto no Colégio Marista quanto no Colégio Loyola, porque eu sempre achei os padres e os irmãos, no caso dos maristas, muito autoritários e atrasados. Mesmo quando criança, eu tive muito problema disciplinar. Até é uma coisa esquisita o Colégio Loyola não ter me expulsado porque eu tive vários problemas disciplinares. Eu era um aluno razoável, mas tive muitos problemas disciplinares de revolta. $\mathrm{E}$ isso foi uma das coisas que, independente da minha prática política, já foi me afastando muito da religião. Apesar de meu pai ser uma pessoa de origem católica e ter sido um importante líder católico aqui em Belo Horizonte. Você vê: tudo o que nós fizemos no Colégio Loyola, de iniciativa política e cultural, os padres eram contra. Nada eles apoiavam. O aluno era o último degrau de uma hierarquia e sua função era só cumprir ordens e dizer sim. Lá não tinha grêmio. A única coisa positiva que eu acho que me lembro desses colégios é o esporte. É a única coisa positiva. Tanto que as minhas filhas nunca estudaram em colégios religiosos. Porque eu considerei minha experiência pessoal, do ponto de vista da minha formação mais geral e da liberdade, um desastre. Eu considerava o ensino religioso e esses colégios católicos um verdadeiro desastre. Pura repressão em matéria política - e sexual, então, nem se fala. Você vê: eu estudei em colégios apenas masculinos durante onze anos. Então, onde a gente encontrava com as moças? A gente encontrava com as moças nas atividades estudantis também, no DCE, nos Congressos Estudantis da Umes [União Municipal de Estudantes Secundaristas], que aí se encontravam. E tinha os colégios públicos para ambos os sexos, o estadual, o municipal. Mas 
esses eram muito mais avançados para a época e, infelizmente, eu não estudei nesses colégios públicos.

M - A sua militância começou pelo Movimento Católico?

LM - É. Se bem que eu nunca fui da Ação Católica, eu já era muito arredio. Mas eu não vim daquele leito comunista, entendeu? Eu nem tinha contatos com o Partido Comunista, sei lá o que mais. Então eu me liguei àquele pessoal que fez diretamente a Ação Popular. Eu entrei na Ação Popular ainda como secundarista, em 1963, quando ela foi fundada. Mas eu convivi muito com o pessoal da JEC, Juventude Estudantil Católica, e JUC, Juventude Universitária Católica, mas eu particularmente já não aceitava fazer parte desse tipo de coisa ligada à hierarquia católica. Por isso que eu me liguei logo à Ação Popular, que já era um movimento totalmente desvinculado da hierarquia católica.

M - Nesse momento da sua prisão em São Paulo, você estava trabalhando como jornalista?

LM - Na verdade, eu estava na clandestinidade, como militante da Ação Popular. Eu não trabalhava como jornalista.

$\mathbf{M}$ - E você declarou ser professor quando foi preso ou isso foi atribuído na sua ficha pelos policiais? Porque nos documentos você consta como professor.

LM - Não. Seguramente eu declarei que era professor porque quando você é preso, em circunstâncias como aquela, de muita repressão, você tinha que inventar alguma história. E a minha história e a do companheiro Marcelo, que foi preso comigo, eram histórias completamente malucas, né. Porque nós não íamos dar nosso endereço, nós estávamos querendo proteger os nossos companheiros, então qual que foi minha história preliminar? Que eu tinha ido para São Paulo, eles sabiam que eu tinha sido dirigente da UNE, isso eles sabiam porque eu tinha ficha, já tinha sido chamado e tal, que eu estava procurando atividades em São Paulo, que meu ponto de referência era o diretório acadêmico da Faculdade de Medicina, que era um diretório com muita estrutura. Eu declarei até que eu dormia lá e que eu era professor de cursinho e estava procurando uma atividade [para] sobreviver. Isso tudo é para quê? Para você escapar de endereço, de nome, disso, daquilo. Você entendeu 
o problema? Quer dizer, você quando é preso numa circunstância daquela, eu ou qualquer outra pessoa, você tem que...

$\mathbf{M}$ - Até para proteger sua família.

LM - A família, os companheiros. A repressão quer puxar a linha, esse é que é o papel dela. Então, eu seguramente falei que eu dava aula porque eu tinha um perfil mais ou menos desse tipo, eu vinha de uma família também, meu pai era muito conhecido, professor universitário... Mas ninguém nunca checou isso. Seguramente foi uma válvula de escape importante para dizer que você estava em alguma coisa. Eu não iria falar: "Olha, estou aqui em São Paulo, clandestino, trabalho para a Ação Popular, moro na Vila Califórnia, sou um militante político profissional, não tenho emprego, a organização é que me sustenta." [...] Quando você era preso, nessa época, a primeira coisa que eles queriam saber, imediatamente, eram os seus pontos. Porque todo militante, eles sabiam, não está sozinho, está ligado a algum coletivo, alguma coisa, então eles querem os contatos, os pontos. Quando eu fui para a tortura pesada, violenta, no Dops de São Paulo, por que o Dops não me entregou pra Oban [Operação Bandeirantes], o que eles queriam saber primeiro eram os pontos. Que pontos você tinha porque a repressão, quando você é preso, ela ainda quer te pegar com aquelas coisas quentes porque se a organização [a] que você pertence percebe sua prisão, se você não apareceu, ela desarticula a ligação. Inclusive, a Ação Popular já tinha tomado uma série de medidas de segurança muito importantes porque você não sabia os endereços dos outros, entendeu? Você tinha pontos, isso você tinha. Eu era dirigente da Ação Popular em São Paulo, então evidentemente que eu tinha pontos. Mas, felizmente, eu não abri nenhum ponto.

M - Mas eles também não sabiam que você era o dirigente?

LM - Não. Inicialmente, não sabiam. Mas quando veio o Cenimar, uns 30 dias depois, o tipo de interrogatório mudou. Aí eles já me identificaram mais ou menos através de outros depoimentos que tinham, já era um serviço de inteligência bem mais sofisticado. Era um pessoal da repressão barra-pesada, fascista, mas era um serviço de inteligência com mais experiência. Então o papo aí não era só ponto, o papo aí já era mais complicado, eles já sabiam que eu era da Ação Popular, que eu era dirigente, né. O papo era primeiro você 
confirmar aquelas coisas para você dizer mais. E a ameaça qual que era? "Vou te entregar de novo para o Fleury, porque você vai para o pau de novo.” Aí que eles me levaram para a Ilha das Flores. Porque a Ilha das Flores, no Rio, era onde o Cenimar concentrava suas investigações e uma das organizações a que dava prioridade era a Ação Popular.

M - Mas também havia tortura no Cenimar. Porque eles te ameaçavam devolver para o Dops?

LM - Havia. O que eu quero dizer para você é o seguinte: o Cenimar, especificamente, não me torturou fisicamente. Ele me sequestrou do Presídio Tiradentes, me colocou em solitária muito tempo, me ameaçou muito. Mas minha família também já estava sabendo que eu estava preso e já havia uma movimentação muito grande. Mas a minha estadia no Rio durante mais ou menos 30 dias, foi totalmente clandestina.

$\mathbf{M}$ - Realmente isso não está nos documentos que eu encontrei.

LM - Não consta. Eu fui sequestrado pelo delegado Fleury e sua equipe, numa manhã, no Presídio Tiradentes, eu e o Marcelo, e nós fomos levados para Ilha das Flores, numa viagem que você pode imaginar como foi. Ficamos lá o tempo todo, isso não consta do meu prontuário oficial. Eu encontrei uma referência de um cara, um ex-torturador já morto, eu encontrei uma referência, uma referência nos arquivos daqui, em Belo Horizonte, que foram encontrados em frente à Assembleia Legislativa, fitas que teriam sido descartadas pelo Dops. [...] A repressão aqui nunca reconheceu que tivesse arquivo nenhum. E, na degravação dessas fitas, tem uma referência a mim feita por esse tenente Marcelo Paixão, um torturador conhecido aqui em Belo Horizonte, de que Luiz Marcos Magalhães Gomes estava na Ilha das Flores naquele momento. Foi a única referência que eu encontrei.

$\mathbf{M}$ - Em uma informação confidencial.

LM - É, é. Em São Paulo eu fiquei no Dops, inicialmente. Fiquei isolado, no chamado "fundão", porque você tem assim, era mais ou menos uma galeria em L e no final da galeria principal havia uma dobra onde se localizavam as celas em que você ficava isolado, o chamado "fundão". Então, inicialmente 
nós ficamos isolados, sendo torturados e tal. Depois nós fomos mandados para o Presídio Tiradentes. No Presídio Tiradentes, em uma manhã, sem nenhum aviso, nenhuma conversa, nós fomos sequestrados pelo delegado Fleury e mais três policiais. Nós não tínhamos a menor ideia para onde eles estavam nos levando. E nós fomos levados diretamente para o Rio, para o cais da Praça XV, pegamos um daqueles barcos até de abertura na frente e fomos para Ilha das Flores. Uns 30 dias depois, nós fomos devolvidos para o Dops, fomos depois novamente enviados para o Presídio Tiradentes. Eu ainda passei por alguns interrogatórios no Dops, mas a barra pesada mesmo foi nos primeiros 40 dias de prisão.

M - E onde você ficava em Ilha das Flores, era um sítio, uma prisão ou o quê?

LM - Era uma ilha mesmo. Eu fiquei na Ilha das Flores, isolado, numa cela sozinho, [...] numa cadeia, cheia de cães, arame farpado, isso, aquilo, etc. e tal. Eu não cheguei a ser levado para esses sítios clandestinos que realmente muitas pessoas com as quais eu estive preso foram posteriormente levadas e morreram nesses sítios. [...] Era um sequestro porque primeiro, quando a repressão te prendia, ela primeiro não reconhecia que tinha te prendido, né. Eu estive preso durante 40 ou 50 dias que a repressão não reconhecia minha prisão. A primeira pessoa que conseguiu me ver no Dops foi um professor eminente de São Paulo, que já faleceu, chamado professor Abrahão de Moraes, um astrofísico famoso da USP. Porque ele era muito amigo de meu pai, ele era uma pessoa muito considerada ali naquele governo Abreu Sodré e ele conseguiu me ver lá no quarto andar do Dops. Isso foi muito importante porque até então eu "não estava preso". E isso é que dava liberdade para a repressão de te torturar, desaparecer com você, se for o caso, né, ou te matar, fazer o que quisessem. Porque o reconhecimento da prisão era assim uma coisa fundamental para sua sobrevivência, porque aí já complicava um pouco. Um pouco, porque a repressão nessa época também não respeitava nada. Teve gente que eventualmente foi reconhecida e foi morta nos famosos acidentes forjados. Por exemplo, eles reconheceram que prenderam o João Baptista Franco Drummond, que foi meu amigo, mas depois falaram que ele morreu num acidente. Só recentemente que houve uma sentença de uma juíza de São Paulo mandando que constasse na certidão de óbito dele que ele morreu no Dops, em virtude de torturas. Porque até então constava na certidão de óbito que ele tinha morrido em um acidente. 
M - É um absurdo, né, até hoje essas coisas não se resolveram. [...]

LM - Isso aí é o seguinte, o que eu tenho a declarar é o seguinte: as forças armadas, no Brasil, nunca passaram por nenhum tipo de transformação democrática. Nenhum. Aquelas forças armadas que forjaram o golpe, que com o auxílio inclusive de grandes capitalistas, latifundiários, mantiveram um regime de ditadura durante 20 anos, que depois perderam toda a condição e inclusive entregaram um país falido, também em virtude da resistência democrática, essas forças armadas nunca passaram, no Brasil, por nenhum processo democrático que pudesse dar uma certa renovação. Não, elas conservam suas mesmas tradições, acham que tudo que elas fizeram foi correto, negam os fatos mais evidentes, negam até mesmo que houve tortura e morte. Tortura em massa. Porque tem esse negócio, essa teoria que a Folha de S. Paulo vende aí, que no Brasil houve uma "ditabranda". Você veja aí agora as declarações desse ex-delegado do Dops do Espírito Santo, esse Cláudio Guerra. Esse negócio de incinerar corpos em usina, em forno de usina de açúcar; de desovar corpos na Lagoa da Pampulha aqui em Belo Horizonte. Ele disse também que aqui um dos "cemitérios" era a Delegacia de Furtos e Roubo, um conhecido antro tenebroso da polícia civil mineira. Quer dizer, isso mostra que não tinha nada de ditabranda, era uma ditadura feroz que torturou e matou muita gente. Se alguém fosse preso nessa época, mesmo que não tivesse ligação com nada, cairia na tortura, porque isso era um procedimento-padrão. Não era só depois que descobriam que você era um militante e tal. Porque se por qualquer motivo você, nessa época, caísse nas mãos da repressão, você tinha $100 \%$ de chance de ser torturado. Claro que os dirigentes, muitos desses, se fossem presos, nem iam sobreviver, como aconteceu com muitos deles. E os militantes que eles descobriam, eles torturavam mais para obter informação. Mas, mesmo pessoas que eventualmente eram presas e que não tinham ligações explícitas com a resistência, essas sofriam tortura. Eu conheci várias pessoas dessas na prisão e que tiveram grande dignidade. Eu conheci, por exemplo, um professor e dentista de Ribeirão Preto que foi indiciado em um daqueles processos da Ação Libertadora Nacional, a ALN, e que era mantido preso porque denunciou, no depoimento na auditoria de guerra, lá em São Paulo, que ele viu torturas e que ele foi torturado. $\mathrm{O}$ juiz auditor queria que ele retirasse esse trecho, ele não retirava e ficou quase dois anos preso por causa disso, porque ele não era propriamente um militante. Pessoa de muita dignidade. Um dentista de Ribeirão Preto, inclusive tratou de muitos presos políticos, a 
mim inclusive no Presídio Tiradentes, no gabinete dentário, que estava abandonado. Ele botou ali pra funcionar, apesar dos recursos serem muito poucos, ninguém dava apoio, nem nada, ele tratou da gente ali.

M - E quando você saiu da prisão, como foi esse retorno para a sociedade civil? Para encontrar emprego, a visão das pessoas, você tinha dificuldade para se relacionar?

LM - Eu acho que você tinha duas coisas: as pessoas mais medrosas evitavam. Eu estive aqui em Belo Horizonte assim meio semiclandestino, porque ainda havia o perigo de ser preso aqui, e houve claramente pessoas que me evitavam. Mas esse não era o tom. A maioria das pessoas te recebia com alegria em saber que você estava vivo, que estava ali. Arrumar emprego era muito difícil porque aí, em termos de empresas, a coisa complicava. Como jornalista, não arrumava emprego em lugar nenhum. Eu arrumei emprego, como te disse, em publicidade. Um de meus cunhados conhecia um grande publicitário mineiro. Eles eram amigos e esse publicitário deu um contato no Rio. Esse pessoal me empregou. Inicialmente eu não tinha carteira de trabalho nem nada mesmo porque meu documento militar estava precisando ser regularizado, quer dizer, não é que eu estava em falta com o serviço militar, não, é que eu não tinha o documento. Então você não podia tirar carteira de trabalho. Eu trabalhei mais de um ano lá no Rio de Janeiro, em publicidade, inicialmente sem carteira de trabalho. Só depois que vim para Belo Horizonte, arriscando muito, e solicitei meu certificado de reservista, é que eu tirei a carteira de trabalho e aí trabalhei uma segunda etapa com carteira assinada. Mas você vê, eu não consegui transferência nem em universidade privada. A Cândido Mendes recusou minha transferência. Não tinha motivo nenhum. Eu tinha prestado vestibular na UFMG, tinha frequentado até o terceiro ano, tinha as cargas horárias das matérias, mas não aceitaram. Eu tive que fazer vestibular. Então, assim, do ponto de vista das pessoas, era o contrário. Você encontrava grande apoio e solidariedade, porque a resistência ao regime era uma resistência muito ampla, havia um sentimento solidário. Mas já em termos de emprego, aí o negócio complicava.

$\mathbf{M}$ - A faculdade pedia algum tipo de atestado de antecedentes criminais?

LM - Não pediram, mas na guia de transferência que a UFMG me forneceu, estava escrito lá: "suspenso de suas atividades por tantos dias", porque foi uma 
greve que eu fiz quando era presidente do diretório e a faculdade me suspendeu. Então essa anotação também, que eles podiam perfeitamente ter evitado, assustava todo mundo. Eles explicitamente não me pediram atestado de bons antecedentes, mas não aceitaram minha transferência. [...] Só consegui entrar depois que prestei vestibular. Aí, eu me transferi para São Paulo, sabe. [... Então eu me desliguei da Cândido Mendes e me transferi para a Fundação Armando Álvares Penteado, onde também minha atitude foi discreta, não houve nenhuma perseguição contra mim. Eles aceitaram a transferência. A única coisa que fizeram foi me mandar de novo para o segundo ano. Fiz várias disciplinas mais de uma vez, acho até que uma, chamada "Introdução ao Direito Público", eu fiz três vezes.

M - Nossa, essa você aprendeu bem! [risos] Durante esse tempo que você ficou preso, a AP ajudava sua esposa financeiramente?

LM - Não, não foi necessário porque minha mulher não era militante e ela foi primeiro acolhida pela família de um físico muito conhecido em São Paulo, o professor Paulus Aulus Pompéia, já falecido, a quem, aliás, eu devo muita gratidão, que acolheu a minha esposa e a minha filha de braços abertos, deu toda a cobertura. A AP não fez contatos com minha esposa, porque, para a segurança de todos, você congelava as relações, sabe, com a organização. A minha mulher ficou mais de um ano sem me ver. Ela teve que esperar meu julgamento para ter - nem a gente queria que ela aparecesse, nem minha filha - para ter o mínimo de segurança porque esse pessoal não respeitava nada. Você sabe do caso de muitos pais, muitas mães cujos filhos foram até torturados, até crianças. Então demorou. Só depois que a minha situação jurídica - eu fui condenado, julgado - foi mais ou menos estabilizada, é que a gente considerou que tinha talvez as condições mínimas da minha mulher me visitar. Ela teve um amplo apoio de famílias amigas mineiras, paulistas, foi muito bem protegida, teve uma retaguarda muito grande de apoio a ela.

M - Seus pais e irmãos não sofreram nenhum tipo de repressão por causa da sua participação ou não conheciam sua família?

LM - Conheciam. Minha família, ao contrário, era muito conhecida. Quando eu fui preso aqui, no Dops e no $12^{\circ} \mathrm{RI}$, em 68, a casa dos meus pais foi invadida. Isso teve muita repercussão aqui porque meu pai era um 
professor universitário. O jornal Estado de Minas, que era o principal jornal aqui, deu a notícia com destaque. O meu irmão, um pouco mais velho do que eu, tinha sido também militante e foi desligado do ITA em 64. Então, na minha família já tinha ocorrido esse caso. E eu tive outros irmãos que tiveram militância, mas não no nível em que eu tive. Meu pai era uma pessoa muito liberal, nunca lutou contra minha militância. Ele respeitava muito as coisas da gente. Ele tinha lá suas opiniões, evidentemente, e meu pai também era uma pessoa que não apoiava a ditadura.

M - Mas na profissão, ele também não sofreu repressões?

LM - Não, ele era físico, professor universitário e com um passado de muita militância católica. Olha, era muito complicado mexer com meu pai. Ele era um líder católico amplamente conhecido, um professor universitário de renome nacional e internacional. Eles iriam falar o que contra meu pai? Ele era um homem independente, era um democrata de origem cristã, sempre foi. É claro que por mais duros que esses regimes todos são, eles também levam em conta a repercussão dessas coisas na sociedade. Quer dizer, eles poderiam ter cassado meu pai, mas seria uma atitude de muito isolamento político também, entendeu. Ah, eles cassaram aqui, por exemplo, o professor Edgar da Mata Machado, que era um líder católico também, pai do estudante que foi morto, José Carlos Novaes da Mata Machado, que foi militante da Ação Popular. O professor Edgar foi afastado, mas ele foi deputado pelo PMDB, foi deputado federal. É uma enorme vergonha, inclusive, para a PUC aqui de Minas, porque a PUC afastou o professor Edgar, um grande democrata e humanista católico, ele teve de parar de dar aulas na Universidade Federal e na Universidade Católica, para você ver como é que as coisas estavam nessa época. Mas meu pai não tinha se metido em partidos, em militância política contra o regime. Ele era uma pessoa com um perfil muito universitário, sabe, muito assim da tradição universitária, da corporação universitária, então era muito complicado, né. Quer dizer, tudo é possível, mas ele não foi atingido pelos atos de exceção.

M - E, durante sua militância, seu objetivo principal era lutar contra a ditadura, mas vocês tinham outras reivindicações também?

LM - Nós lutávamos. O que começou como uma resistência contra a ditadura, isso foi evoluindo. No auge da nossa militância, em termos estratégicos, 
nós queríamos implantar no Brasil uma sociedade socialista. Nós achávamos que essa era a grande transformação que o país tinha que passar.

$\mathbf{M}$ - Aí já inspirados pelo marxismo?

LM - É, exato, por influência também de outros países, da China. A União Soviética, na época, não tinha muito "Ibope" com a gente porque a gente achava que ela já estava numa linha bastante negativa, digamos assim, contra as tradições revolucionárias. Mas nós também éramos militantes socialistas e comunistas.

$\mathbf{M}$ - E depois vocês desistiram da ideia do socialismo ou mantiveram até o final do movimento?

LM - A organização, a Ação Popular, ela ali em 1971, em que eu estava preso, ela rachou. A chamada "maioria" resolveu se incorporar ao PC do B e uma outra parte resolveu prosseguir com a Ação Popular Marxista-Leninista, APML. Essa parte da APML foi praticamente destruída pela repressão. Depois, acho que o pessoal remanescente dela entrou no PT. Quando eu saí da prisão, as pessoas com quem eu tinha mais vínculo na minha militância, ou a maioria delas, tinham ido para o PC do B. Como eu estava na luta legal, ali no Opinião, no Movimento, os contatos comigo eram assim muito raros. Mas eu continuava com a mesma ideologia, como continuo até hoje. Atualmente, não sou ligado a nenhum desses partidos. O PC do B diz que luta pelo socialismo. Eu acho que, se ele luta, ele luta de uma maneira completamente equivocada, por isso que eu me afastei dele. O PT, eu vou te dizer a verdade, eu nunca acreditei nessa proposta. Nunca. E hoje ele comanda aí, na minha opinião, um regime altamente conservador que, na essência, é o mesmo projeto do Fernando Henrique Cardoso, do PSDB. Tem diferenças, não é igualzinho mas, na essência, é o mesmo projeto do capital financeiro do Fernando Henrique Cardoso. Então, eu nunca tive ilusão com o PT. Eu nunca fui petista. Me afastei do PC do B porque achei que esse partido também abandonou uma perspectiva revolucionária. Não é que eu acho que eu sozinho estou certo, não. Eu acho que tem muitas pessoas, iguais a mim, que estão espalhadas por aí e têm essa visão. Mas hoje, nós estamos em um momento de muita dispersão, de muita fragmentação, de muito isolamento, de muita dificuldade. Então, é difícil aparecerem alternativas que não as que estão institucionalmente visíveis aí. [...] 
M - Você citou várias ações que fez aqui, mas você participou também de ações armadas?

LM - Não. Eu, especificamente, nunca participei de ações armadas porque, primeiro, a linha da minha organização não era essa. Era como eu te disse: ela passou por um breve período foquista, inclusive foi ela quem fez aquela explosão da bomba no aeroporto de Guararapes, no Recife, no governo Costa e Silva, mas isso foi uma coisa muito passageira. Nós estudamos os textos do Che Guevara, do Régis Debray, mas o período foquista da Ação Popular foi muito pequeno. Logo depois, como eu te disse, ela evoluiu para uma concepção de guerra popular e aí era mais ou menos o seguinte, também simplificadamente: os que ficavam nas cidades, onde o inimigo era muito forte, faziam basicamente trabalho político revolucionário de organização, agitação e luta de massas, não estavam ligados necessariamente à luta armada, e os que iam para o interior, para o campo, começavam a preparar ali as bases da guerrilha... Foi essa concepção que originou depois, pelo PC do B, a Guerrilha do Araguaia. Então eu sempre estive ligado à luta de massas na cidade, por isso que eu nunca me liguei, especificamente, às ações armadas. Eu me liguei a greves, panfletagem, comícios, manifestações, dentro dessa concepção de guerra popular. Nós achávamos que nós estávamos preparando a resistência armada. Mas na organização que eu pertencia, não era papel nosso preparar as ações armadas dentro das cidades, porque a gente achava isso uma aventura. Eu não estou condenando quem fez isso: a VPR [Vanguarda Popular Revolucionária], a VAR-Palmares [Vanguarda Armada Revolucionária Palmares], a Ação Libertadora Nacional, o Comando de Libertação Nacional - Colina, etc. Esse pessoal todo achou que essa era uma estratégia e uma tática mais adequada. A nossa concepção é que não era, porque é o que eu te disse: nessas cidades, o inimigo era muito forte. Você ia fazer ações armadas iniciais com resultado, mas a reação que viria seria muito pesada e você não ia aguentar. Então, a Ação Popular, em termos gerais, não se envolveu em ações armadas nas grandes cidades.

M - E como você reflete, hoje, sobre sua atuação durante a ditadura? Você continua com as mesmas posições ou repensou alguma coisa?

LM - Olha, arrepender nunca me passou pela cabeça. Eu acho que aqui teve uma ditadura feroz, como na maioria dos países latino-americanos, dentro 
de um contexto de Guerra Fria, de anticomunismo, de reação à Revolução Cubana. Então, nunca me passou pela cabeça nenhum tipo de arrependimento. Nem acho que eu pessoalmente tenha feito nada essencialmente errado. Claro que nós éramos jovens, tínhamos convicção que íamos mudar o mundo, tínhamos uma energia muito grande. Felizmente nós nos ligamos à luta de massas, como a gente dizia, à luta concreta. A luta de massas não é produto de conspiração. Tem gente que acha que as passeatas, as manifestações eram coisas de meia dúzia de gente. Isso é uma concepção ridícula e que não explica nada. Como é que meia dúzia de gente vai fazer 20 mil, 30 mil operários entrarem em greve? Se eles não estiverem dispostos a enfrentar aquelas coisas, eles não vão. Por mais que meia dúzia faça, não adianta nada. Agora, acho que a coisa complicou para nós, no nosso campo, para quem tem essa visão anticapitalista, etc., como eu tenho. A coisa não está fácil para nós, porque houve muitas mudanças no mundo, houve essa onda neoliberal inteira, que atingiu até os países mais avançados onde os direitos mais elementares hoje estão em risco. Desde os direitos trabalhistas, a previdência social, tudo isso está sendo destruído. Então, eu acho que nós estamos em um momento, ao contrário do momento que nós passamos, de muita desmobilização, fragmentação, etc. Hoje você não tem uma ditadura aberta como aquela, de maneira nenhuma, mudou muito, mas também acho que você tem baixa resistência, pelo menos visível. Eu acho isso ruim porque os problemas pelos quais nós lutamos, as grandes contradições de exploração, de opressão, mesmo de direitos elementares, persistem em grande parte do planeta. Você pega o Brasil. Houve aqui um processo de redemocratização? Houve. O processo de redemocratização foi por baixo ou foi por cima? Foi por cima, foi negociado. A resistência teve influência nesse processo? Evidente que teve, e muita. Os governos que se seguiram ao processo de redemocratização, qual a natureza deles? Basicamente conservadores. Tanto os do PSDB quanto os do PT, na essência, conservadores. Não trouxeram nada de mudança qualitativa daquilo que a gente sempre considerou. Nada. Você continua tendo um governo cuja função principal é pagar os rentistas, os detentores da dívida pública, dar aí umas esmolas de bolsa-família, não sei o que mais. Isso pode fazer diferença em um país tão atrasado como era o Brasil e com contrastes sociais tão evidentes, mas você vê que aqui são os poderosos que mandam, até nas coisas mais elementares. Então quer dizer, as oligarquias no Brasil não foram atingidas, continuam aí, continuam mandando e esse negócio de PT aí, isso é perfumaria. Não quer dizer que eu ache que a gente lutou em vão, 
não. Não foi. Mas as mudanças qualitativas que nós buscávamos não foram feitas não, elas continuam aí na ordem do dia. Mudou muita coisa. Posso dizer para você que talvez a minha visão não seja exatamente a de quando eu tinha 25 anos, mas acho que o sentimento básico é o mesmo. Eu tenho 66 anos e acho que o sentimento básico de que nós estamos numa sociedade "fim da picada" em que uma oligarquia e uma plutocracia, essas coisas desses poderosos em geral que mandam e desmandam. Eu não considero que isso aqui seja uma democracia efetiva. É como já disse um revolucionário, nossa atual situação é um pouco a seguinte: "De quatro em quatro anos você tem a liberdade de escolher qual setor da oligarquia vai dirigir o país nos quatro anos seguintes." Eu não te passo isso como uma visão amarga, não. Estou falando como eu vejo as coisas. Agora, não me acode absolutamente nenhum sentimento de arrependimento.

M - As questões que eu trouxe eram essas. Você quer falar mais alguma coisa, fazer alguma outra consideração?

LM - Não, era isso. Eu consideraria que seria um grande avanço se realmente se instalasse no país uma Comissão da Verdade - que fosse da Verdade mesmo - e trouxesse à tona todos esses acontecimentos tão fundamentais para o povo brasileiro conhecer e que, em sua grande parte, continuam obscurecidos. Com todas essas teorias enganosas desses grandes veículos de comunicação de que aqui teve uma ditabranda. Não, não foi uma ditabranda. Aqui teve uma ditadura violenta e que, evidentemente, se conformou com o perfil do Brasil. Na Argentina, era outro perfil. No Uruguai, outro perfil. No Chile, outro perfil. Mesmo porque lá no Chile você teve um processo político, com o governo Allende, que avançou mais do que o do presidente João Goulart, então a reação lá foi muito mais violenta. O presidente João Goulart resolveu sair do Brasil justificando que não queria provocar derramamento de sangue. O Allende resolveu não sair e ficou lá. No fundamental, eram as mesmas reformas - que até hoje nunca foram feitas. E esses governos atuais não são nem reformistas. O governo João Goulart não pretendia fazer nenhuma revolução no Brasil, era um governo reformista num contexto de agudização da luta de classes. O governo do PT não é nem reformista. Que reforma básica ele propõe ou realizou? Nenhuma.

$\mathbf{M}$ - Bom, eu agradeço pela entrevista! Obrigada! 
Resumo: Luiz Marcos de Magalhães Gomes foi um importante militante político durante o regime militar no Brasil. Devido à sua grande participação no movimento estudantil e na organização chamada Ação Popular, ele atraiu para si a atenção de órgãos repressores, tendo sido preso por motivos políticos. Sua entrevista fornece elementos importantes para a compreensão dos movimentos de resistência à ditadura e da repressão organizada pelo governo.

Palavras-chave: regime militar brasileiro, militância política, Ação Popular, movimento estudantil, repressão.

\section{Dictatorship, repression and resistance: memories of a political militant}

Abstract: Luiz Marcos de Magalhães Gomes was an important political militant during the military regime in Brazil. Due to his intense involvement in the student movement and in the organization called Ação Popular, he drew away the attention of repressive organs, having been arrested for political reasons. His interview provides important elements for understanding the movements of resistance to dictatorship and repression organized by the government.

Keywords: Brazilian military regime, political militancy, Ação Popular, student movement, repression.

Recebido em 01/10/2012

Aprovado em 14/11/2012 